"Mircea cel Batran" Naval Academy Scientific Bulletin, Volume XIX - 2016 - Issue 1

Published by "Mircea cel Batran" Naval Academy Press, Constanta, Romania // The journal is indexed in:

PROQUEST / DOAJ / DRJI / JOURNAL INDEX / I2OR / SCIENCE LIBRARY INDEX / Google Scholar / Crossref /

Academic Keys / ROAD Open Access / OAJI / Academic Resources / Scientific Indexing Services / SCIPIO

\title{
DETERMINATION OF RELEVANT FEATURES OF A SCALE MODEL FOR A 55000 DWT BULK CARRIER NECESSARY TO STUDY THE SHIP MANEUVERABILITY
}

\author{
Alecu TOMA ${ }^{1}$ \\ Mironiuk WALDEMAR ${ }^{2}$ \\ Mihail PRICOP ${ }^{3}$ \\ ${ }^{1}$ Asistent professor, Eng., PhD, „Mircea cel Batran” Naval Academy, Constanta, Romania, \\ alecu.toma@anmb.ro \\ ${ }^{2}$ Associate professor, PhD, Polish Naval Academy, GDYNIA, Poland, W.Mironiuk@amw.gdynia.pl \\ ${ }^{3}$ Associate professor, Eng., PhD, „Mircea cel Batran” Naval Academy, Constanta, Romania, \\ mihail.pricop@anmb.ro
}

\begin{abstract}
The study method of a ship behavior based on practical tests on scale models is widely used both leading scientists and engineers, architects and researchers in the naval field. In this paper we propose to determine the parameters of a ship handling characteristics relevant to study the 55,000 dwt bulk carrier using a scale model. Scientific background for practical experimentation of this techniques necessary to built a scale model ship consists in applying the principles of similarity or "similitude". The scale model achieved by applying the laws of similarity must allow, through approximations available in certain circumstances, finding relevant parameters needed to simplify and solve the Navier-Stokes equations. These parameters are necessary for modeling the interaction between hull of the real ship and the fluid motion.
\end{abstract}

Keywords: ship, similarity, similitude, modeling, manoeuvring.

\section{General modelling and scaling laws}

It is known that in terms of cost and scientific research accessibility (the Navier-Stokes equations are so complex that it is unrealistic and unrevealing to search for the most general solutions) to study a ship maneuverability, tests are performed on a geometrically scaled model, obtained from the real ship by uniformly scaling, rather than on the full-scale prototype. For a specific physical problem, such as a ship moving in the sea, there are usually some obvious scales of motion. The less obvious ones can also be derived by physical considerations. For the problems above the length or draft of the ship is the obvious length scale. The time from the start of the ship motion can be the time scale. The speed of the ship are the natural scales for the velocity. If gravity is expected to be important the gravitational acceleration can be used as the scale of body force per unit mass.

The continuity equation contains no parameter; however, the momentum equation (Navier Stokes) reveals the Reynolds number $(R e)$ which is an useful dimensionless parameter in fluid mechanics. The $R e$ is formed by the ratio of density $(\rho)$, characteristic speed $(U)$, and characteristic length $(L)$ to viscosity $(\mu)$, defined as:

$$
R e=U L / \mu=U L / N
$$

Alternatively, it is the ratio of characteristic speed and length to kinematic viscosity, defined as:

$$
v=\mu / \rho
$$

and,

$$
R e=U L / N
$$

The Froude number $(F r)$ is the dominant effect in free surface flows, defined as:

$$
F r=U^{2} / g L
$$

where $g$ is gravitational acceleration.

According with [6]:

- inertial forces are proportional with $\rho U^{2} L^{2}$

- frictional forces are proportional with vUL

- gravitational forces are proportional with $\rho g L^{3}$

The total resistance of ship is given by:

$$
R_{T}=C_{T}\left(\rho U^{2} S\right)
$$

where $S$ is wetted surface of the ship.

The resistance of model ship is measured and translates to scale model of one of the methods [1], ITTC 1957, Huges-Prohaska, ITTC 1978, Telfer (GEOSIM).

In a general flow field, the similarity between a model and prototype is achieved only when there is geometric similarity, kinematic similarity, and dynamic similarity [2].

\subsection{Geometric similarity}

To fulfil geometric similarity the model must be the same shape as the real ship, but scaled by constant scale factor.

$$
\lambda=L_{r} / L_{m}=B_{r} / B_{m}=d_{r} / d_{m}
$$

where: index " $r$ " designates a dimension of a real ship and index,$m$ " designates a dimension of a model ship, $L$ is the length of the ship, $B$ is the breadth of the ship, $d$ is the draft of the ship. 
"Mircea cel Batran" Naval Academy Scientific Bulletin, Volume XIX - 2016 - Issue 1

Published by "Mircea cel Batran" Naval Academy Press, Constanta, Romania // The journal is indexed in: PROQUEST / DOAJ / DRJI / JOURNAL INDEX / I2OR / SCIENCE LIBRARY INDEX / Google Scholar / Crossref /

Academic Keys / ROAD Open Access / OAJI / Academic Resources / Scientific Indexing Services / SCIPIO

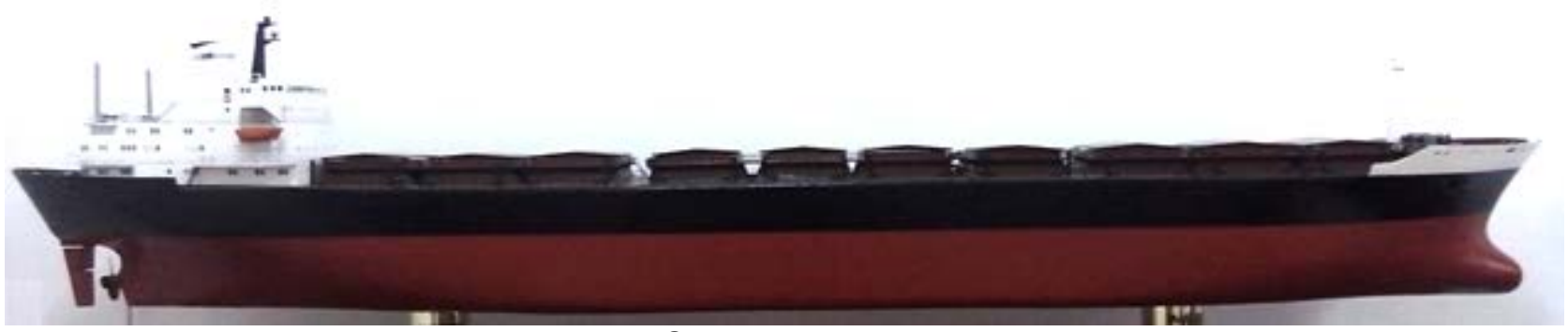

Fig. 1 Scaled ship - side view

All linear dimensions must have the same scale ratio. This applies also to the environment surrounding and elastic deformations of the model and ship.

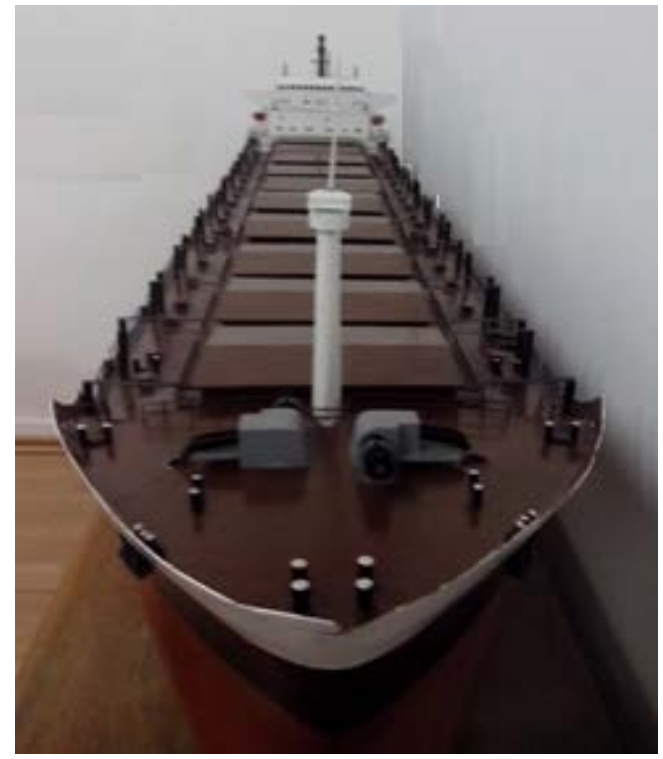

Fig. 2 Scaled ship - front view

\subsection{Kinematic similarity}

A kinematic similarity occurs when the velocity at any point in the model flow must be proportional to the velocity at the corresponding point in the real flow so that a circular motion in full scale must be a circular motion also in model scale. The ratio between propeller tip speed and advance speed must be the same for model ship and real ship. Time scale $\lambda_{t}$ as a relation of the time in real life phenomena to the time corresponding to it in a model-related phenomenon is expressed by the dependence:

$$
\lambda_{t}=\mathrm{t}_{\mathrm{r}} / \mathrm{t}_{\mathrm{m}}
$$

Thus a kinematic scale can be presented by means of a geometric scale and time scale:

$$
\lambda v=\lambda / \lambda_{\mathrm{t}}
$$

According () and () both $R_{e}$ and $F_{r}$ similarity criteria can be met only if the tests are carried out on the real ship.
If we adopt the same $R e$ for model and real ship, the speed of scaled ship can be calculated with the following equation:

$$
U_{m}=U_{r}\left(L_{r} / L_{m}\right)
$$

If we adopt the same $\mathrm{Fr}$ for model and real ship, the speed of scaled ship can be calculated with the following equation:

$$
U_{m}=U_{r}\left(L_{m} / L_{s}\right)
$$

Since the real possibilities for testing models at high speeds are limited in practice we use the $\mathrm{Fr}$ similarity criteria and the $R e$ for model ship is :

$$
R e_{r}=\lambda^{3 / 2} R e_{m}
$$

Because the $R e$ criterion is not met we will get some differences of similarity called scale effects that must be estimated in order to extrapolate correctly.

\subsection{Dynamic similarity}

For dynamic similarity all forces in the model flow scale by a constant factor to corresponding forces in the prototype flow.

To ensure complete similarity we would need to use a liquid whose kinematic viscosity satisfies required ratio of kinematic viscosity to match boht Re and Fr:

$$
\left(\mathrm{V}_{\mathrm{m}} / \mathrm{V}_{\mathrm{r}}\right)=\left(\mathrm{L}_{\mathrm{m}} / \mathrm{L}_{\mathrm{r}}\right)^{3 / 2}
$$

Required for a model liquid with the scale factor $\mathrm{L}_{\mathrm{m}} / \mathrm{L}_{\mathrm{r}}=1 / 100$ (atmospheric pressure, $\mathrm{T}=20^{\circ} \mathrm{C}$, and $\left.\mathrm{v}_{\mathrm{r}}=1,002 \times 10^{-6} \mathrm{~m}^{2} / \mathrm{s}\right)$ is:

$$
\begin{gathered}
V_{\mathrm{m}}=\mathrm{V}_{\mathrm{r}}\left(\mathrm{L}_{\mathrm{m}} / \mathrm{L}_{\mathrm{r}}\right)^{3 / 2} \\
=\left(1,002 \times 10^{-6} \mathrm{~m}^{2} / \mathrm{s}\right)(1 / 100)^{3 / 2}=10^{-9} \mathrm{~m}^{2} / \mathrm{s}
\end{gathered}
$$

Because there is no such a liquid (even the mercury has the kinematic viscosity at the level of $10^{-7} \mathrm{~m}^{2} / \mathrm{s}$ ) it is not possible to match both $R e$ and $\mathrm{Fr}$ between model and real ship and we are forced to settle for incomplete similarity.

The resistance forces acting on model ship will be measured and extrapolated for full scale ship using the equality of the $\mathrm{Fe}$ at model and full scale ship (real ship).

Scaling laws allows testing models instead of expensive large real ship. There are rules for finding scaling laws or conditions of similarity. If the similarity condition exists:

$$
R e_{m}=R e_{r}
$$

and we can write the scaling law equation:

$$
F_{r} / F_{m}=\left(\rho_{r} / \rho_{m}\right)\left(V_{r} / V_{m}\right)^{2}\left(L_{r} / L_{m}\right)^{2}
$$


"Mircea cel Batran" Naval Academy Scientific Bulletin, Volume XIX - 2016 - Issue 1

Published by "Mircea cel Batran" Naval Academy Press, Constanta, Romania // The journal is indexed in: PROQUEST / DOAJ / DRJI / JOURNAL INDEX / I2OR / SCIENCE LIBRARY INDEX / Google Scholar / Crossref /

Academic Keys I ROAD Open Access / OAJI / Academic Resources / Scientific Indexing Services / SCIPIO

were $F_{r}$ and $F_{m}$ designates a forces accting of a real ship and scaled ship.

If we measure the model force at the model Reynolds number $\left(R e_{m}\right)$, the prototype force at the same Reynolds number $\left(R e_{r}\right)$ equals the model force times the density ratio times the velocity ratio squared times the length ratio squared.

\section{Determination constructive parameters of} the model ship

2.1 Calculation the structural dimensions of the model ship

The characteristics of the 55.000 dwt bulk carrier are:

\begin{tabular}{|c|c|c|c|}
\hline \multicolumn{2}{|c|}{ TONNAGES } & \multicolumn{2}{c|}{ MACHINERY DETAILS } \\
\hline GT & 32100 & POWER & $12799 \mathrm{KW}$ \\
\hline NT & 23043 & REVOL. SPEED & $122 \mathrm{rpm}$ \\
\hline DWT & 54615 & PROPELLERS & FBP \\
\hline \multicolumn{2}{|c|}{ DIMENSIONS } & SPEED & Gnots \\
\hline LOA & $220.00 \mathrm{~m}$ & NO. OF HOLDS & $75516 \mathrm{~m}^{3}$ \\
\hline LBP & $205.50 \mathrm{~m}$ & NO. OF HATCHES & 1 \\
\hline B & $32.30 \mathrm{~m}$ & & 10 \\
\hline D & $17.00 \mathrm{~m}$ & & \\
\hline HOLD LENGTHS & $16.80,28.80,17.10,27.00$, & & \\
\hline HATCHES DIMENS. & $17.10,29.70,15.30$ & & \\
\hline
\end{tabular}

To have exactly the same shape as the 55.000 dwt bulk carrier we divide all the dimensions of the ship (length, breadth, draught, etc) by the scale factor $\lambda$.

We establish the scale factor $\lambda=100$ and we can calculate all the structural dimensions of the model ship, and the most important are:

\begin{tabular}{|c|c|c|}
\hline $\begin{array}{c}\text { DIMENSION } \\
\mathrm{S}\end{array}$ & $\begin{array}{c}55.000 \text { DWT } \\
\text { BULK } \\
\text { CARRIER }\end{array}$ & SCALED SHIP \\
\hline LOA & $220.00 \mathrm{~m}$ & $220 \mathrm{~cm}$ \\
\hline LBP & $205.50 \mathrm{~m}$ & $205.50 \mathrm{~cm}$ \\
\hline $\mathrm{B}$ & $32.30 \mathrm{~m}$ & $32.30 \mathrm{~cm}$ \\
\hline $\mathrm{D}$ & $17.00 \mathrm{~m}$ & $17.00 \mathrm{~cm}$ \\
\hline$d$ & $12.40 \mathrm{~m}$ & $12.40 \mathrm{~cm}$ \\
\hline $\begin{array}{c}\text { HOLD } \\
\text { LENGTHS }\end{array}$ & $\begin{array}{c}16.80,28.80 \\
17.10,27.00 \\
17.10,29.70 \\
15.30 \mathrm{~m}\end{array}$ & $\begin{array}{c}16.80,28.80 \\
17.10,27.00 \\
17.10,29.70 \\
15.30 \mathrm{~cm}\end{array}$ \\
\hline $\begin{array}{l}\text { HATCHES } \\
\text { DIMENS. }\end{array}$ & $\begin{array}{c}10 *(11.70 * 15.6 \\
0) \mathrm{m}\end{array}$ & $\begin{array}{c}10 *(11.70 * 15.6 \\
0) \mathrm{cm}\end{array}$ \\
\hline
\end{tabular}

The area scale factor is:

$$
\lambda_{A}=\lambda^{2}=100^{2}
$$

The similarly areas of the model ship are $10^{4}$ times smaller than on the real ship.

The volume scale factor is:

$$
\lambda_{v}=\lambda^{3}=100^{3}
$$

The similarly volumes on the model ship are $10^{6}$ times smaller than on the real ship.
It is important to note that the angles, length ratios, such as $L / B, L / d$, or the block coefficient $D /(L x B x d)$ are the same on both model and real ship.

2.2 Calculation of mass for the model

To use a model ship in scientific researche implies that if a model is subject to similar forces as real ship, it must move like her. This is called „similarity of mass".

The scale factor for mass and displacement is the same as for volumes, as sea water and the water in the researche laboratory have very nearly the same specific gravity. Hence,

$$
\lambda_{M}=\lambda^{3}=100^{3}=10^{6}
$$

The DWT of the model ship is $54615 \times 10^{3} / 10^{6}=$ $54,615 \mathrm{~kg}$. In addition to total displacement, however, the weights of the different parts of the ship also need scaling down correctly.

\begin{tabular}{|c|c|c|}
\hline TONNAGES & $\begin{array}{c}55.000 \text { DWT } \\
\text { BULK } \\
\text { CARRIER }\end{array}$ & $\begin{array}{c}\text { SCALED } \\
\text { SHIP }\end{array}$ \\
\hline $\begin{array}{c}\text { Gross tonnage } \\
\text { (GT) }\end{array}$ & 32100 tones & $32.100 \mathrm{~kg}$ \\
\hline $\begin{array}{c}\text { Nett tonnage } \\
\text { (NT) }\end{array}$ & 23043 tones & $23.043 \mathrm{~kg}$ \\
\hline
\end{tabular}

It would be very difficult indeed to do this down to the last detail, and fortunately only the following need reproducing to scale for present purposes:

a. The exact position of the centre of gravity for the considered ship's load distribution.

b. The exact moments of inertia of the ship about the three axes. 
"Mircea cel Batran" Naval Academy Scientific Bulletin, Volume XIX - 2016 - Issue 1

Published by "Mircea cel Batran" Naval Academy Press, Constanta, Romania /I The journal is indexed in: PROQUEST / DOAJ / DRJI / JOURNAL INDEX / I2OR / SCIENCE LIBRARY INDEX / Google Scholar / Crossref /

Academic Keys / ROAD Open Access / OAJI / Academic Resources / Scientific Indexing Services / SCIPIO

The above have to be measured on the model and should be adjusted by ballasting with iron plates as required. We will consider two sets of plates: one set should be equivalent to the full load condition, and another set of plates should be equivalent to the "ballast" condition.

\subsection{Similarity of forces}

If in addition to shape, mass and inertia the forces causing ship's motion are "similar", the motion will also be "similar".

Such forces are caused by sea or weather conditions, e.g. wind, current, waves or generated by the ship herself, e.g. propeller thrust, rudder moment, or else they may be due to hydraulic effects caused by the sea bed or a canal bank. They will be correctly reproduced if they are to the same scale as weight and mass, i.e. if their scale factor is:

$$
\lambda_{F}=\lambda_{M}=\lambda^{3}=10^{6}
$$

\subsection{Similarity of time and motions}

Motion is a function of distance and time, and for similarity of motion, therefore, it is necessary to give special consideration to the time scale problem.

In other way the time scale factor $\lambda_{\mathrm{t}}$ is not the same as $\lambda$, but as $\lambda^{1 / 2}$, and this holds good for all forms of motion considered here. It also gives us the following scale factors:

$$
\lambda_{s}=N \lambda_{t}=\lambda^{1 / 2}=10
$$

Angular rudder rate or r.p.m. =angle/time

$$
\begin{aligned}
\text { Power } & =\text { force } \times \text { speed } \\
=\lambda_{P}=\lambda_{F} \times \lambda_{S} & =\lambda^{3} \times \lambda^{1 / 2}=\lambda^{3,5}
\end{aligned}
$$

In other words:

a) The model is ten times slower than the real ship, but as distances are one hundred times shorter on the model, the model time are ten times shorter too.

b) Angular motion is ten times faster on the model, e.g. the following: angular rudder rate; ship's turning rate for a given rudder angle; yaw and R.P.M.

\section{Manoeuvring similarity}

To illustrate the application of these various scales, we consider a 55,000 DWT ship under way maintaining a constant full speed of 16 knots at 122 r.p.m. It will thus cover 4 miles (about 34 ship's lengths) in 15 minutes.

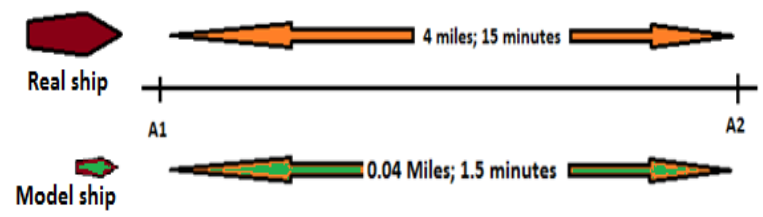

Fig. 3 Ship under way

The corresponding distance equivalent to 34 ship's lengths for the ship model is only of 0.04 mile $(=4 / 100)$, which the model covers in about 1,5 minutes $(15 / 10)$ at a speed of $16 / 10=1.6$ knots at $122 \times 10=1220$ r.p.m.

\begin{tabular}{|c|c|c|}
\multicolumn{1}{c}{$\lambda_{a}=1 / \lambda_{t}=1 / \lambda^{1 / 2}=1 / 10$} & $(21)$ \\
\hline $\begin{array}{c}55.000 \text { dwt bulk } \\
\text { carrier }\end{array}$ & $220 \mathrm{~m}$ & \\
\hline Scale factor & $\begin{array}{c}\text { Ship lenght } \\
\times 1 / 100\end{array}$ & \\
\hline $\begin{array}{c}\text { Ship model } \\
\mathbf{1 / 1 0 0}\end{array}$ & $220 \mathrm{~cm}$ & \\
\hline \multicolumn{3}{|c|}{ is another example. Supposing the same }
\end{tabular}

Turning is another example. Supposing the same rudder angles $\left(35^{\circ}\right)$ are set simultaneously on the
55,000 DWT bulk carrier and the model travelling at $16 \mathrm{kts}$ and $1.6 \mathrm{kts}$ respectively; after 4 minutes, the real ship will have turned through 180 degrees, with a tactical diameter of about 3 ship lengths, i.e. $660 \mathrm{~m}$, whereas the model will only take 24 seconds (4/10) to turn through the same angle, with the same 3 ship length tactical diameter, but equivalent to $660 \mathrm{~cm}$ (660/100). The real ship's angular turning rate works out at 45 degrees/min, compared to 7,5 degrees/sec $\left(45^{\circ} / \min \times 10\right)$ for the model.
21)

\begin{tabular}{l|c|c|c|}
$\begin{array}{l}34 \text { ship } \\
\text { lengths }\end{array}$ & $16 \mathrm{kn}$ & 15 minutes & 122 \\
$\begin{array}{l}\text { Distance } \\
\mathrm{x} 1 / 100\end{array}$ & $\begin{array}{c}\text { Ship speed } \\
\times 1 / 10\end{array}$ & $\begin{array}{c}\text { Time } \\
\times 1 / 10\end{array}$ & $\begin{array}{c}\text { RPM } \\
\times 10\end{array}$ \\
$\begin{array}{l}34 \text { model } \\
\text { lenghts }\end{array}$ & $1,6 \mathrm{kn}$ & 1,5 minutes & 1220 \\
\hline
\end{tabular}

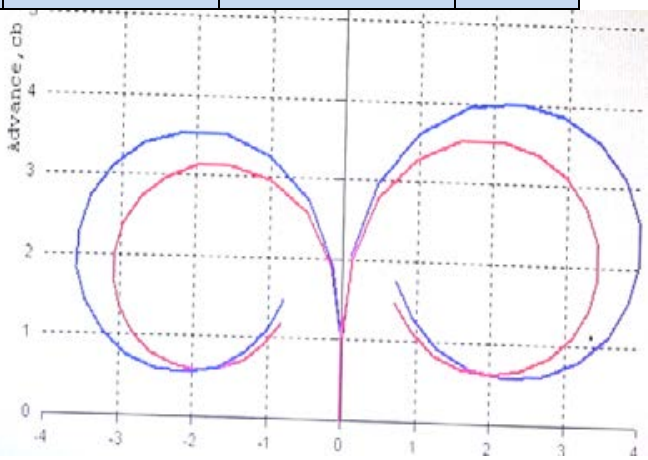

Fig. 4 Turning circle of the real ship

Finally, let us consider ship's motion in a rough sea, for example pitching. The pitch angle depends on the ratio between the ship's length and the wave length. 
"Mircea cel Batran" Naval Academy Scientific Bulletin, Volume XIX - 2016 - Issue 1 Published by "Mircea cel Batran" Naval Academy Press, Constanta, Romania // The journal is indexed in: PROQUEST / DOAJ / DRJI / JOURNAL INDEX / I2OR / SCIENCE LIBRARY INDEX / Google Scholar / Crossref / Academic Keys / ROAD Open Access / OAJI / Academic Resources / Scientific Indexing Services / SCIPIO

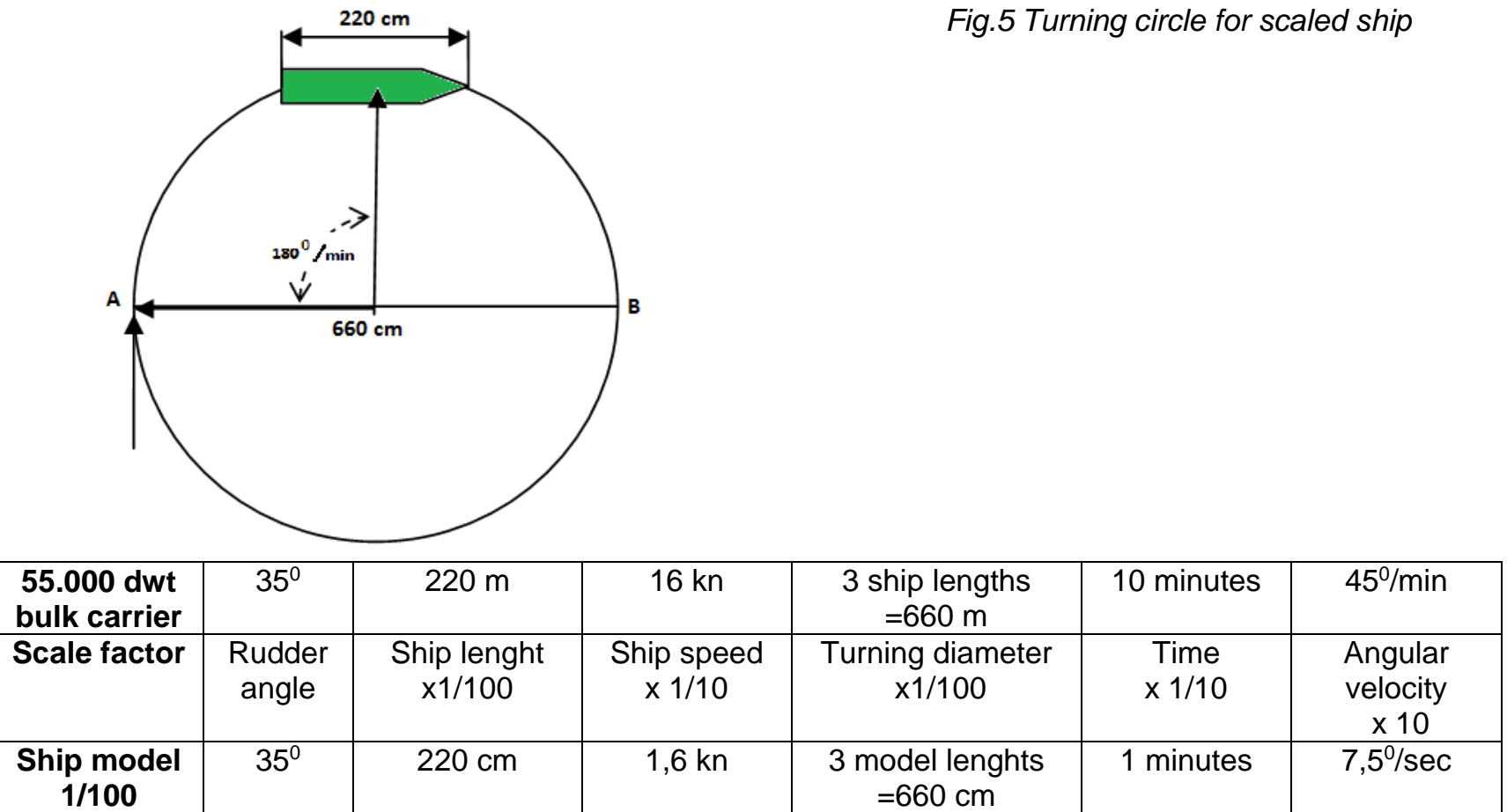

\section{CONCLUSIONS}

The study method of a ship behavior based on practical tests on scale models is widely used both leading scientists and engineers, architects and researchers in the naval field. Handling tests with self-propelled model have to be made in accordance with the recommendations of $[9,10,11]$ Manoeuvring trial code of ITTC, IMO Circular MSC 389 and Rezolutia IMO A 601 din 1987. All linear dimensions of the scaled ship must have the same scale ratio. This applies also to the environment surrounding and elastic deformations of the model and ship. The model ship will be equipped with propulsion and steering systems, systems for measuring parameters of motion and emission reception systems. Handling tests on model scale is achieved being adopted Fr similarity criteria. Because the Re similarity criteria is not met the scale effects must be correct estimated in order to extrapolate.

\section{BIBLIOGRAPHY}

[1] Bertram, V., Practical ships hidrodynamics, Butterworth Heinemann, Oxford 2000.

[2] Bahrami, M., Dimensional Analysis and Similarity.

[3] Derett, D., 1999. Ship stability for Masters and Mates. Oxford: Butterworth-Heinemann.

[4] Lungu A., Modelari numerice in hidrodinamica, Ed. Tehnica, Bucuresti 2000.

[5] Maier V., Mecanica si constructia navei, Ed. Tehnica, Bucuresti 1985.

[6] Obreja D., Teoria Navei, Concepte si metode de analiza a performantelor de navigatie, Editura didactica si pedagogica Bucuresti 2005, ISBN 973301 401-X

[7] Obreja D., si altii, Manevrabilitatea navei, Galati University Press 2008, ISBN 9789738871199

[8] Waldemar Mironiuk, Model-based investigations on dynamic ship heels in relation to maritime transport safety, the archives of transport, Volume 33, Issue 1, 2015, e-ISSN (online): 2300-8830

[9] $]^{\star \star \star}$ Manoeuvring trial code of ITTC, 1975

$[10]^{\star * *}$ IMO Circular MSC 389

[11] *** Rezolutia IMO A 601 din 1987

[11] *** Rezolutia IMO A 751 din 1993 